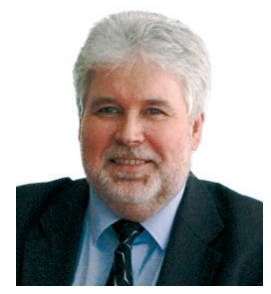

Aleksey A. ILYUKHIN

Cand. Sc. (Econ.), Professor of Political Economy Dept.

Ural State University of Economics 620144, RF, Yekaterinburg,

8 Marta/Narodnoy Voli St., 62/45

Phone: (343) 221-27-52

E-mail: diplom@uralweb.ru

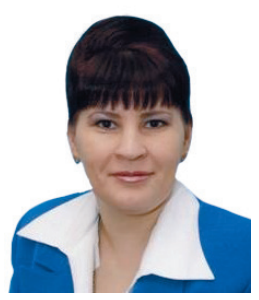

Svetlana V. ILYUKHINA

Cand. Sc. (Econ.), Associate Professor of Statistics, Econometrics and Information Science Dept.

Ural State University of Economics 620144, RF, Yekaterinburg, 8 Marta/Narodnoy Voli St., 62/45

Phone: (343) 221-27-39

E-mail: diplom@uralweb.ru

\section{Keywords}

HAPPINESS ECONOMICS

FACTORS OF HAPPINESS

CONDITIONS OF HAPPINESS

YOUNG PEOPLE

HAPPINESS EVALUATION

\title{
Happiness Economics: \\ The Role, Opinions and Evaluations by Young People
}

\section{Abstract}

Searching for the sources of economic growth and stimulating economic activity of people, especially the youth, in the context of a transition to a new technological mode in modern Russia are the main priorities for economic science. Encouraging economic activity under new conditions is associated with a search for novel sources and direction for implementation. From this standpoint, economic policy is of special importance since it ensures welfare and other aspects of happiness as an economic phenomenon. The article focuses on the economic category of happiness, as well as the issues of objective and subjective assessments of happiness by the young audience. The purpose of the paper is to examine the economic phenomenon of happiness from the perspective of subjective assessments of the younger generation and to identify general objective factors and conditions that determine happiness. The authors apply the quantitative and qualitative methods of statistical analysis: time series, the ranking method, rank correlation, correlation and regression analysis and econometric modeling. We rank socio-economic factors, material wealth and conditions that create happiness, study subjective opinions of young people about happiness, and establish general objective factors and conditions of happiness of the younger generation. The authors also reveal that material conditions and socio-psychological factors are the elements of a single system which, when interacting, produce a synergy effect generating a qualitatively new motivation for enhancing economic activity that ensures effective self-realization, especially among young people.

\section{INTRODUCTION}

There are two main reasons behind the relevance of the paper's subject matter. The first one is associated with the search for new economic growth factors, or activation of the known ones (but yet underestimated), in the context of the sixth technological mode, the core factors of which include: nanotechnologies, stem cells and methods of genetic engineering, alternative energy, etc. The second reason is linked with the necessity to form an effective motivational environment for the younger generation under abrupt structural shifts in economy.

With a high degree of reliability, we can assert that research studies in the field of happiness economics can provide the required motivational environment in the conditions of new technological changes in society. This thesis is confirmed by the fact that many leading scientists, including three Nobel laureates in economics - Joseph Stiglitz, Daniel Kahneman and George Akerlof, express their interest in this sphere of economic theory. They regard happiness as an economic category that mirrors a balanced combination of material wealth, social equilibrium, physical health and time [11; 13; 14; 17].

The purpose of the article is to investigate the economic category of happiness from the standpoint of subjective evalua- tions of the younger generation and identify the subjective factors and conditions that determine happiness.

To achieve the stated goal, the following tasks should be performed:

1) to evaluate the ratio between the objective and the subjective in the formation of happiness;

2) to study subjective assessments of happiness by young people and identify general objective factors and conditions for happiness of the younger generation;

3) to establish the avenues for using the obtained results to form the motivational environment of young people (aged 18-23) in terms of economic activity.

\section{HAPPINESS AS AN ECONOMIC CATEGORY: THE OBJECTIVE AND THE SUBJECTIVE}

There are numerous publications on happiness that seek to reveal the happiness-forming factors and classify them into economic and non-economic. Many researchers argue that these factors include income, health, social status, marital status, rights and political freedom $[9 ; 10 ; 16]$. For instance, according to Jeffrey Sachs, an American economist from Columbia University who was a co-editor of the World Happiness Report, happiness is an important category that can be clearly assessed [15]. 


\section{Экономика счастья: \\ роль, взгляды и оценки молодежи}

\section{Аннотация}

Поиск источников экономического роста, мотивация хозяйственной деятельности людей, особенно молодежи, в условиях перехода к новому технологическому укладу в современной России являются приоритетными для экономической науки. Мотивация хозяйственной деятельности в новых условиях связана с поиском новых источников и направлений реализации. Перспективной с этих позиций является экономическая политика, обеспечивающая благосостояние и другие аспекты счастья как экономического феномена. В статье рассмотрена экономическая категория счастья, а также вопросы объективных и субъективных оценок счастья молодежной аудиторией. Цель статьи - исследование экономического феномена счастья с точки зрения субъективных оценок молодого поколения современного общества и выделение общих объективных факторов и условий, определяющих счастье. Применялись количественные и качественные методы статистического анализа: ряды динамики, методы ранжирования, ранговой корреляции, корреляционно-регрессионного анализа, эконометрического моделирования. Ранжированы социально-экономические факторы, материальные блага и условия, формирующие ощущение счастья. Проведено исследование субъективных оценок молодежи в понимании счастья и выделение общих, объективных факторов и условий счастья молодого поколения. Выявлено, что материальные условия и социально-психологические факторы являются элементами единой системы, во взаимодействии рождающими синергетический эффект, вызывающий качественно новую мотивацию хозяйственной деятельности, обеспечивающей эффективную самореализацию, особенно в среде молодежи.

The issues of happiness economics are also actively studied by Russian scientists, such as O.N. Antipina, A.D. Nekipelov, R.S. Grinberg, S. Guriev, V.S. Bochko, Ye. Zhuravskaya, K. Teteryatnikov $[1 ; 3 ; 5 ; 7$; 8; 12].

For example, O.N. Antipina claims that economic factors of happiness encompass "the degree of the economic development of a country as a whole, the level of implementation of the factors covered by the Global Competitiveness Report (including the availability and quality of medical, educational, insurance and recreational services), the sources and size of income, and job" [2. P. 96].

Non-economic factors that influence the state of happiness are "age, gender, personal qualities of an individual, social status, involvement in the life of society, observing religious rituals, leisure, and living conditions" [2. P. 97].

The concept of happiness in terms of sensations is a subjective category, but on the basis of the aforementioned studies of the leading scientists we can assume that happiness as an economic category is founded on objective factors, and their identification allows determining the directions for forming economic motivation of an individual. We also can deduce that the central factors of economic growth in the context of new technological changes are provided by not only the human factor per se, but by young people with a clear economic motivation. In our opinion, young people are the major link capable of ensuring the individualization of production and consumption, producing a principal decrease in energy intensity and material intensity of production, designing materials and organisms with predetermined properties and implementing other achievements of the sixth technological mode [6].

In the course of the socio-economic study, we try to identify some generalized essence-related factors and characteristics inherent in groups of people with similar traits and inclinations. Subjective approaches distinguish between aspects of quality of life and objective factors that shape them: cognitive assessments and positive and negative effects. For example, we have found that, despite having lower income, young people are happier than able-bodied population of middle age. This is attributed to hopes for future success in life and specific features of perception: respondents have stressed that the most important sources of happiness for them were opportunities for self-realization, confidence in future, family, children and good health. This confirms the hypothesis that young people determine a new quality
И^ЮХИН Алексей Александрович

Кандидат эКономических наук, профессор кафедры политической экономии Уральский государственный
экономический университет
620144, РФ, г. Екатеринбург, ул. 8 Марта/Народной Воли, 62/45 Tел.: (343) 221-27-52

E-mail: diplom@uralweb.ru

И^ЮХИНА Светлана Викторовна Кандидат экономических наук, Аоцент кафедры статистики, эконометрики и информатики

Уральский государственный экономический университет 620144, РФ, г. Екатеринбург, ук. 8 Марта/Народной Воли, 62/45 Тел.: (343) 221-27-39

E-mail: diplom@uralweb.ru

Ключевые слова

ЭКОНОМИКА СЧАСТЬЯ

ФАКТОРЫ СЧАСТЬЯ

УСЛОВИЯ СЧАСТЬЯ

МОЛОДЕЖЬ

ОЦЕНКА СЧАСТЬЯ 


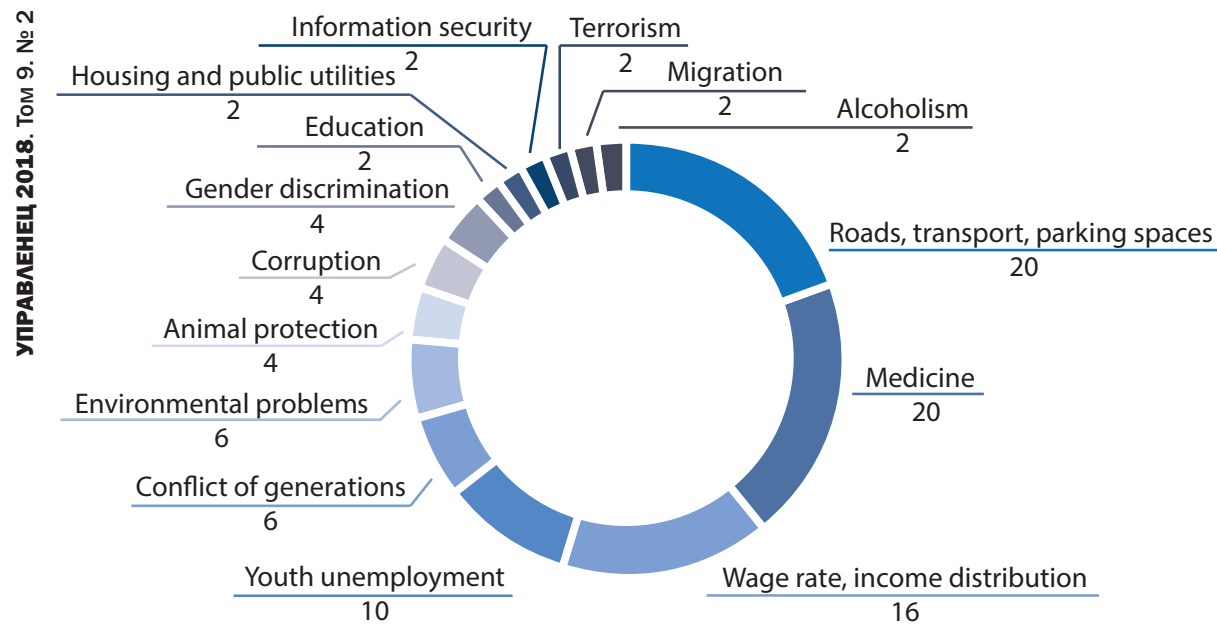

Fig. 1. Problems of Russian young people, \% of total

Compiled by the authors using questionnaire results.

Table 1 - Structure and ranking of the categories studied

\begin{tabular}{|c|c|c|c|}
\hline Factors of happiness & $\%$ & $\begin{array}{l}\text { Material objects and actions } \\
\text { producing the state of happiness }\end{array}$ & $\%$ \\
\hline $\begin{array}{l}\text { Own health and health of family } \\
\text { members }\end{array}$ & 17.5 & Money & 17.65 \\
\hline Love and family & 16.5 & Car & 13.03 \\
\hline Loyalty of close friends & 11.7 & Personal house/apartment & 11.76 \\
\hline Making other people happy & 5.4 & Travel/vacation & 11.00 \\
\hline Personal growth & 4.4 & Sleep and food & 7.14 \\
\hline Confidence in life and oneself & 4.4 & Job & 4.62 \\
\hline Travel & 4.4 & New clothes & 4.20 \\
\hline Care & 4.4 & Successful marriage & 2.94 \\
\hline Satisfaction with what you do & 4.4 & Business & 2.52 \\
\hline Positive emotions & 4 & Sweets & 2.52 \\
\hline Drive, extreme & 3 & Alcohol & 2.10 \\
\hline Achieving goals and fulfilling dreams & 3 & $\begin{array}{l}\text { Extreme sports: parachuting, hot air } \\
\text { balloon flight, snowboarding equipment }\end{array}$ & 2.10 \\
\hline Feeling of freedom & 2 & Pets & 2.10 \\
\hline Sense of beauty & 2 & Relocating to the city of dream & 1.68 \\
\hline Inspiration & 2 & Success in sports & 1.68 \\
\hline Ease & 1.5 & $\begin{array}{l}\text { Build a house for parents, provide for } \\
\text { them }\end{array}$ & 1.68 \\
\hline Inner perception of the world & 1.5 & Music & 1.68 \\
\hline Pleasure of purchasing & 1.5 & $\begin{array}{l}\text { Beauty (lash extensions, manicure, } \\
\text { cosmetics) }\end{array}$ & 1.26 \\
\hline Children & 1.5 & $\begin{array}{l}\text { Gadgets: PC, GoPro (action cameras), } \\
\text { music players }\end{array}$ & 1.26 \\
\hline Success & 0.9 & Acquaintance with a celebrity, concerts & 1.26 \\
\hline Good music & 0.9 & Education, passing exams & 1.26 \\
\hline Harmony & 0.9 & Sauna, resuming hot water supply & 1.26 \\
\hline Euphoria & 0.4 & Gifts for the loved ones & 0.84 \\
\hline Pleasant company & 0.4 & Entertainment & 0.84 \\
\hline Memories & 0.4 & Regaining excellent health & 0.42 \\
\hline Comfort & 0.4 & To get into the past & 0.42 \\
\hline $\begin{array}{l}\text { Understanding that it is normal to } \\
\text { make mistakes }\end{array}$ & 0.4 & Doing what you love & 0.42 \\
\hline
\end{tabular}

Calculated by the authors using the findings of the online sociological research. of economic growth under the conditions of radical technological changes.

\section{METHODOLOGY AND ANALYSIS OF FACTORS AND CONDITIONS OF YOUNG PEOPLE'S HAPPINESS}

In our study, we performed a quantitative analysis of interconnection and interdependence of qualitative indicators of happiness. We applied different combinations of methods of structural analysis, interviewing, ranking and correlation and regression analysis. Socio-economic factors, material objects and subjective sensations are regarded as criteria for pinpointing the problem of happiness formation. Within the framework of the current research study, about 700 young people (aged 18-23) were interviewed.

Young people with their desires, aspirations and problems are the future of any society. Problems of the youth are of a permanent character, regardless of an epoch. Along with desires, aspirations and dreams, problems are generally the same among young people of different eras and social formations. The difference lies in a combination of public, collective and individual goods that civilization provides at the current stage of human development. The authors discover and rank the central problems that beset Russian young people (Fig. 1).

The distribution of the spectrum of problems revealed that young people are primarily concerned with the road and transport problem, including parking spaces, and healthcare (20\% of respondents each), which is quite understandable from the viewpoint of caring about their own health and health of the loved ones. Transport embodies a desire and necessity to be mobile in their personal life and pursue a successful career.

Wage rate and income distribution occupy second place (16\% of respondents); it is followed by youth unemployment (10\%), which is explained by the age of the respondents who are now gaining education and parental support. Environmental problems and conflict of generations account for $6 \%$ each; animal protection, gender discrimination and corruption - 4\% each; alcoholism, education, housing and public utilities, information security, terrorism and migration - $2 \%$.

The primary purpose of the study was to examine happiness, as young people understand it. For this purpose, a maximum number of factors, objects and actions that bring a sense of happiness was identified. 
Table 2 - Calculation of Spearman's rank correlation coefficient between material objects and the state of happiness

\begin{tabular}{|c|c|c|c|c|c|c|}
\hline$N$ & A values & Rank A & B values & Rank B & d (Rank A - Rank B) & $d^{2}$ \\
\hline 1 & 17.65 & 27 & 17.5 & 27 & 0 & 0 \\
\hline 2 & 13.03 & 26 & 16.5 & 26 & 0 & 0 \\
\hline 3 & 11.76 & 25 & 11.7 & 25 & 0 & 0 \\
\hline 4 & 11.0 & 24 & 5.4 & 24 & 0 & 0 \\
\hline 5 & 7.14 & 23 & 4.4 & 21 & 2 & 4 \\
\hline 6 & 4.62 & 22 & 4.4 & 21 & 1 & 1 \\
\hline 7 & 4.2 & 21 & 4.4 & 21 & 0 & 0 \\
\hline 8 & 2.94 & 20 & 4.4 & 21 & -1 & 1 \\
\hline 9 & 2.52 & 18.5 & 4.4 & 21 & -2.5 & 6.25 \\
\hline 10 & 2.52 & 18.5 & 4 & 18 & 0.5 & 0.25 \\
\hline 11 & 2.1 & 16 & 3 & 16.5 & -0.5 & 0.25 \\
\hline 12 & 2.1 & 16 & 3 & 16.5 & -0.5 & 0.25 \\
\hline 13 & 2.1 & 16 & 2 & 14 & 2 & 4 \\
\hline 14 & 1.68 & 12.5 & 2 & 14 & -1.5 & 2.25 \\
\hline 15 & 1.68 & 12.5 & 2 & 14 & -1.5 & 2.25 \\
\hline 16 & 1.68 & 12.5 & 1.5 & 10.5 & 2 & 4 \\
\hline 17 & 1.68 & 12.5 & 1.5 & 10.5 & 2 & 4 \\
\hline 18 & 1.26 & 8 & 1.5 & 10.5 & -2.5 & 6.25 \\
\hline 19 & 1.26 & 8 & 1.5 & 10.5 & -2.5 & 6.25 \\
\hline 20 & 1.26 & 8 & 0.9 & 7 & 1 & 1 \\
\hline 21 & 1.26 & 8 & 0.9 & 7 & 1 & 1 \\
\hline 22 & 1.26 & 8 & 0.9 & 7 & 1 & 1 \\
\hline 23 & 0.84 & 4.5 & 0.4 & 3 & 1.5 & 2.25 \\
\hline 24 & 0.84 & 4.5 & 0.4 & 3 & 1.5 & 2.25 \\
\hline 25 & 0.42 & 2 & 0.4 & 3 & -1 & 1 \\
\hline 26 & 0.42 & 2 & 0.4 & 3 & -1 & 1 \\
\hline 27 & 0.42 & 2 & 0.4 & 3 & -1 & 1 \\
\hline Total & & 378 & & 378 & 0 & 52.5 \\
\hline
\end{tabular}

Calculated by the authors using the findings of the online sociological research.

We aimed to establish the major factors guaranteeing moral and physical balance of young people and the state of happiness, since this is exactly the feeling that, in our opinion, generates the greatest motivation of a young person in all spheres of life, and primarily in economic activity. The following results were obtained (Table 1).

The ranking of 10 factors of happiness demonstrated that "Own health and health of family members", "Love and family", "Loyalty of close friends" achieved above $10 \%$ of the total vote each, whereas "Making other people happy", "Confidence in life and oneself", "Travel", "Care", "Satisfaction with what you do" and "Positive emotions" range from 5.4 to $4 \%$.

First priority for all the respondents is family and everything related to it in terms of material well-being (food and shelter) and health. Second priority is given to hobby/job that brings both financial and emotional satisfaction. Personal house/ apartment, "preferably cosy and comfortable", and having a partner for life come third. Fourth priority is sincere and loyal friends and money (a need for communication and mutual benefit). Fifth priority is an opportunity to travel, buy a car and gratify the desire to be mobile. Self-realization comes sixth. The last priority is passing exams, pets, children and business, which is explained by the age group of the respondents.

These are primarily family and health that give the respondents the emotional state of happiness; family peace comes second; friends and love occupy third place; sincere relationships and feelings, respect in society, realizing plans and dreams and doing what you love share fourth place; joy, "satisfaction in life, the desire to live, sport, God, expectation of something good and world peace" are in fifth place.
The study revealed that the overwhelming majority of the respondents (90\%) are indisputably happy, while the rest of them (10\%) consider themselves rather happy, since they have important components of happiness, such as "a loving family, friends, I am acquiring education, I have a place to live and what to eat".

Next, we examined the interconnection and interdependence between material objects, sensations and problems that concern young people. To confirm the proposed hypothesis and to assess the strength (tightness) of the correlation between two attributes or two profiles (hierarchies) of attributes, we calculated the rank correlation coefficient $r_{s}$ by the Spearman method [4] using the following formula:

$$
r_{s}=1-6 \frac{\sum d^{2}}{N\left(N^{2}-1\right)} .
$$

To achieve that, we ranked the aggregate of material objects that, in the opinion of the respondents, bring happiness and sensations, which they cause if they are in the presence, while fulfilling the criteria limiting the calculation of this coefficient (Table 2).

Critical values for $N=27$.

\begin{tabular}{|c|c|c|}
\hline \multirow{2}{*}{$N$} & \multicolumn{2}{|c|}{$p$} \\
\cline { 2 - 3 } & 0.05 & 0.01 \\
\hline 27 & 0.38 & 0.49 \\
\hline
\end{tabular}

$H_{0}$ - the null hypothesis is rejected, the correlation between $A$ and $B$ is recognized to be statistically significant, since Spearman's correlation coefficient is greater than the critical values $r_{s}=0,984>0,38$. Hence, the correlation between "happiness as a sensation" and "material objects bringing the state of happiness" is reliable and confirms the presence of a close direct positive correlation. The econometric model for correlation is the following:

$$
\begin{aligned}
& \hat{y}(x)=a+b x ; \\
& \hat{y}(x)=a+0,984 b .
\end{aligned}
$$

After that, we ranked the aggregate of problems and sensations, which they cause if they are in the presence, while fulfilling the criteria limiting the calculation of this coefficient (Table 3).

Critical values for $N=15$.

\begin{tabular}{|c|c|c|}
\hline \multirow{2}{*}{$N$} & \multicolumn{2}{|c|}{$p$} \\
\cline { 2 - 3 } & 0.05 & 0.01 \\
\hline 15 & 0.52 & 0.66 \\
\hline
\end{tabular}

$H_{0}$ - the null hypothesis is rejected, the correlation between $A$ and $B$ is recognized to be statistically significant and reliable, since Spearman's rank correlation coefficient is above the critical values and con- 


\begin{tabular}{|c|c|c|c|c|c|c|}
\hline$N$ & A values & Rank A & B values & Rank B & d (Rank A - Rank B) & $d^{2}$ \\
\hline 1 & 20 & 14.5 & 17.5 & 15 & -0.5 & 0.25 \\
\hline 2 & 20 & 14.5 & 16.5 & 14 & 0.5 & 0.25 \\
\hline 3 & 16 & 13 & 11.7 & 13 & 0 & 0 \\
\hline 4 & 10 & 12 & 5.4 & 12 & 0 & 0 \\
\hline 5 & 6 & 10.5 & 4.4 & 9 & 1.5 & 2.25 \\
\hline 6 & 6 & 10.5 & 4.4 & 9 & 1.5 & 2.25 \\
\hline 7 & 4 & 8 & 4.4 & 9 & -1 & 1 \\
\hline 8 & 4 & 8 & 4.4 & 9 & -1 & 1 \\
\hline 9 & 4 & 8 & 4.4 & 9 & -1 & 1 \\
\hline 10 & 2 & 3.5 & 4 & 6 & -2.5 & 6.25 \\
\hline 11 & 2 & 3.5 & 3 & 4.5 & -1 & 1 \\
\hline 12 & 2 & 3.5 & 3 & 4.5 & -1 & 1 \\
\hline 13 & 2 & 3.5 & 2 & 2 & 1.5 & 2.25 \\
\hline 14 & 2 & 3.5 & 2 & 2 & 1.5 & 2.25 \\
\hline 15 & 2 & 3.5 & 2 & 2 & 1.5 & 2.25 \\
\hline Total & & 120 & & 120 & 0 & 23 \\
\hline
\end{tabular}

Calculated by the authors using the findings of the online sociological research.

firms the presence of a close positive correlation between the presence of objects, factors and problems that determine the state of happiness of young people. The econometric model for correlation is the following:

$$
\hat{y}(x)=a+0,959 b .
$$

The model with sufficient reliability confirms that the selected material objects, factors and economic activities provide $95.9 \%$ $\left(r_{s}=0,959\right)$ of happiness and the sense of balance for young people. At that, despite the fact that the set of factors, objects and actions is perceived by each respondent individually and is different in importance for each of them, for the entire group under study the factors are the same. This allows us to talk about the objectivity of the main factors and causes that explain the phenomenon of happiness of young people, and they should be utilized to shape the motivational environment of the youth to encourage their economic activity.

\section{CONCLUSION AND DIRECTIONS FOR FURTHER RESEARCH}

The conducted research allowed the authors to ascertain the following important facts. For every person, the feeling of happiness has its own, unique meaning that is associated with events taking place in their life. It can manifests itself in material values, physical comfort, mutual affection, etc. Happiness is a feeling of full satisfaction with everything in life, harmony with others and with the world as a whole; realization that someone needs you, that you are loved and you love back and are capable of doing everything.

For every person, happiness consists in a combination of sensations and material values. It is impossible to be fully happy having lots of money but no friends and family. A certain range of desires will always be present in life of every person, and happiness is the ability to implement and fulfil their plans in a competent manner.

Happiness is an emotional and psychological state of a person that is determined by a high degree of satisfaction with life during a specific period of time. Happiness is a balance between material and spiritual satisfaction. After all, to be healthy - you need money for treatment, to be happy with shopping - you need money as well. The level of success of an individual depends on the level of happiness. Based on the findings of the study, we can make the following principal observations and conclusions:

1) happiness, as an equilibrium state of a person, is determined by a variety of factors, which encompass those dependent on the subjective assessments of an individual, but the main components of such an equilibrium are certainly the same for all;

2) it is incorrect to separate material conditions from socio-psychological factors ensuring a comfortable equilibrium for a person and the maximum possible motivation in all spheres of life;

3) material conditions and socio-psychological factors are the elements of a single system that, when interacting, create a synergy effect associated primarily with effective economic self-realization, especially among young people;

4) material conditions for the youth create not only a comfortable standard of living, but also a sense of prestige, significance and confidence in economic activity;

5) the younger generation, its economic motivation and activity will determine the pace of economic growth in the conditions of the transition to the sixth technological mode.

The obtained results indicate that in further studies it is necessary to identify not only the ranked factors and conditions of happiness of a person, but it is required to try to model the socio-economic conditions that will shape the factors and conditions of happiness among young people, who, ideally, should act as the basis of the state's economic policy in conditions of the new technological mode.

Библиографическая ссылка: Илюхин А.А., Илюхина С.В. Экономика счастья: роль, взгляды и оценки молодежи // Управленец. 2018. T. 9. №2. C. 12-17. DOI: 10.29141/2218-5003-2018-9-2-3.

For citation: Ilyukhin A.A., Ilyukhina S.V. Happiness Economics: The Role, Opinions and Evaluations by Young People. Upravlenets The Manager, 2018, vol. 9, no. 2, pp. 12-17. DOI: 10.29141/2218-5003-2018-9-2-3. 


\section{Источники}

1. Антипина О.Н. Экономика, культура и счастье: есть ли взаимосвязь? // Мировая экономика и международные отношения. 2017. Т. 61. №7. C. 35-44.

2. Антипина О.Н. Экономическая теория счастья как направление научных исследований // Вопросы экономики. 2012. №2. С. 94-107.

3. Бочко В.С. Теория экономического счастья человека: необходимость формирования и направления поиска // Журнал экономической теории. 2012. № 4. С. 7-18.

4. Гмурман В.Е. Теория вероятностей и математическая статистика. М.: Высшая школа, 2003.

5. Гринберг Р.С. Экономика и счастье // Научные труды Вольного экономического общества России. 2014. Т. 181. С. 14-25.

6. Илюхин А.А., Илюхина С.В. Социальная инфраструктура и внутренняя трудовая миграция // Известия Санкт-Петербургского государственного экономического университета. 2015. №3(93). С. 20-24.

7. Некипелов А.Д. Экономическая теория как наука о счастье // Научные труды Вольного экономического общества России. 2014. Т. 181. C. 101-107.

8. Тетерятников К. Экономика счастья и системообразующие банки // Финансовая жизнь. 2014. №2. С. 49-60.

9. Akerlof G.A., Kranton R.E. Identity and the Economics of Organizations // Journal of Economic Perspectives. 2005. Vol. 19. No. 1. P. 9-32.

10. Blanchflower D.G., Oswald A.J. International Happiness // NBER Working Paper. 2011. No. 16668. URL: www.nber.org/papers/w16668.

11. Deaton A., Stone A. Two happiness puzzles // American Economic Review: Papers \& Proceedings. 2013. Vol. 103(3). P. 591-597.

12. Guriev S., Zhuravskaya E. (Un)happiness in Transition // Journal of Economic Perspectives. 2009. Vol. 23(2). P. 143-168.

13. Kahneman D. Thinking, Fast and Slow. N.Y.: Farrar, Straus and Giroux, 2013.

14. Kahneman D., Tversky A. Prospect theory: An analysis of decision under risk // Econometrica. 1979. Vol. 47. P. 313-327.

15. Sachs J.D. First World Happiness Report Launched at the United Nations. URL: http://www.earth.columbia.edu/ articles/view/2960.

16. Simon H.A. Models of Bounded Rationality. Cambridge, Mass.: MIT Press, 1982.

17. Stiglitz J.E., Sen A., Fitoussi J.-P. Report by the Commission on the Measurement of Economic Performance and Social Progress, 2009. P. 12. URL: www. stiglitz-sen-fitoussi.fr/en/index.htm.

\section{References}

1. Antipina O.N. Ekonomika, kul'tura i schast'e: est' li vzaimosvyaz'? [Economy, culture and happiness: Is there interconnection?]. Mirovaya ekonomika i mezhdunarodnye otnosheniya - World Economy and International Relations, 2017, vol. 61, no. 7, pp. 35-44.

2. Antipina O.N. Ekonomicheskaya teoriya schast'ya kak napravlenie nauchnykh issledovaniy [The economic theory of happiness as a direction of scientific research]. Voprosy ekonomiki - Issues of Economy, 2012, no. 2, pp. 94-107.

3. Bochko V.S. Teoriya ekonomicheskogo schast'ya cheloveka: neobkhodimost' formirovaniya i napravleniya poiska [The theory of economic happiness of the man: Necessity for formation and direction of search]. Zhurnal ekonomicheskoy teorii - Journal of Economic Theory, 2012, no. 4, pp. 7-18.

4. Gmurman V.Ye. Teoriya veroyatnostey $i$ matematicheskaya statistika [Theory of probability and mathematical statistics]. Moscow:Vysshaya shkola Publ., 2003.

5. Grinberg R.S. Ekonomika i schast'e [Economy and happiness]. Nauchnye trudy Vol'nogo ekonomicheskogo obshchestva Rossii - Proceedings of the Free Economic Society of Russia, 2014, vol. 181, pp. 14-25.

6. Ilyukhin A.A., llyukhina S.V. Sotsial'naya infrastruktura i vnutrennyaya trudovaya migratsiya [Social infrastructure and internal labour migration]. Izvestiya Sankt-Peterburgskogo gosudarstvennogo ekonomicheskogo universiteta - Journal of St. Petersburg State University of Economics, 2015, no. 3(93), pp. $20-24$.

7. Nekipelov A.D. Ekonomicheskaya teoriya kak nauka o schast'e [Economic theory as science of happiness]. Nauchnye trudy Vol'nogo ekonomicheskogo obshchestva Rossii - Proceedings of the Free Economic Society of Russia, 2014, vol. 181, pp. 101-107.

8. Teteryatnikov K. Ekonomika schast'ya i sistemoobrazuyushchie banki [Economic of happiness and system-forming banks]. Finansovaya zhizn' Financial Life, 2014, no. 2, pp. 49-60.

9. Akerlof G.A., Kranton R.E. Identity and the Economics of Organizations. Journal of Economic Perspectives, 2005, vol. 19, no. 1, pp. 9-32.

10. Blanchflower D.G., Oswald A.J. International Happiness. NBER Working Paper No. 16668. 2011. Available at: www.nber.org/papers/w16668.

11. Deaton A., Stone A. Two happiness puzzles. American Economic Review: Papers \& Proceedings, 2013, vol. 103(3), pp. 591-597.

12. Guriev S., Zhuravskaya Ye. (Un)happiness in Transition. Journal of Economic Perspectives, 2009, vol. 23(2), pp. 143-168.

13. Kahneman D. Thinking, Fast and Slow. N.Y.: Farrar, Straus and Giroux, 2013.

14. Kahneman D., Tversky A. Prospect theory: An analysis of decision under risk. Econometrica, 1979, vol. 47, pp. 313-327.

15. Sachs J.D. First World Happiness Report Launched at the United Nations. Available at: www.earth.columbia.edu/articles/view/2960.

16. Simon H.A. Models of Bounded Rationality. Cambridge, Mass.: MIT Press, 1982.

17. Stiglitz J.E., Sen A., Fitoussi J.-P. Report by the Commission on the Measurement of Economic Performance and Social Progress, 2009. P. 12. URL: www. stiglitz-sen-fitoussi.fr/en/index.htm. 